\title{
SEROPREVALENCE OF MOSQUITO-BORN AND TICK-BORN MICROORGANISMS IN HUMAN POPULATION OF SOUTH BACKA DISTRICT
}

Ivana Hrnjaković Cvjetković' ${ }^{1,21}$, Tamaš Petrovićs ${ }^{3}$ Dušan Petrić 4 , Dejan Cvjetković, ${ }^{2,5}$, Gordana Kovačević ${ }^{1}$, Jelena Radovanov ${ }^{1}$, Aleksandra Jovanović Galović ${ }^{1}$, Aleksandra Patić, ${ }^{1,2}$, Nataša

Nikolić $^{1,2}$, Sandra Stefan Mikić ${ }^{2,5}$, Vesna Miloševićc ${ }^{1,2}$

${ }^{1}$ Institute for Public Health of Vojvodina, Novi Sad, Republic of Serbia

${ }^{2}$ University of Novi Sad, Faculty of Medicine Novi Sad, Republic of Serbia

${ }^{3}$ Scientific Veterinary Institute "Novi Sad", Novi Sad, Republic of Serbia

${ }^{4}$ University of Novi Sad, Faculty of Agriculture, Novi Sad, Republic of Serbia

${ }^{5}$ Clinical Center of Vojvodina, Department of Infectious

Diseases, Novi Sad, Republic of Serbia

\section{Abstract}

Chikungunya virus is an Arbo virus belonging to the family Togaviridae. In urban areas, antropophilic Aedes aegypti and Aedes albopictus mosquitoes are vectors for virus transmission to human population. Chikungunya virus has attracted the professional and scientific public attention in 2013 causing a massive outbreak on the American continent. In Europe, autochthonous transmissions of Chikungunya virus infections have been recorded in Italy in 2007 as well as in France in 2010 and 2014. Usutu virus is a RNA virus from the family Flaviviridae. The virus circulates in a transmission cycle between wild birds and Culex mosquitoes. The virus has been detected in numerous bird species across Europe. Manifestations recorded in humans include meningoencephalitis and skin rash. First human cases in Europe were recorded in immunocompromised individuals in Italy in 2009. Spirochete Borrelia burgdorferi sensu lato is transmitted to humans by ticks and causes Lyme disease, a multisystemic disease with dermatological, neurological, cardiological or articular manifestations. Ninety three persons interviewed about risk factors for vector-borne infections were examined. The examination was performed using commercial ELISA IgG for Chikun-

${ }^{1}$ Corresponding author: ivana.hrnjakovic@izjzv.org.rs, ivana.hrnjakovic-cvjetković@mf.uns.ac.rs 
gunya and Usutu virus and ELISA IgM and IgG test for Borrelia burgdorferi in line with manufacturer's instructions (Euroimmun, Germany). Out of 93 examined individuals Usutu virus specific IgG antibodies were identified in $7.5 \%$ (7/93) persons. The results of ELISA IgG test for Chikungunya virus were negative in the majority of tested samples, whereas 7.5\% (7/93) of samples revealed borderline result. In 9.7\% (9/93) participants, antibodies against Borrelia burgdorferi were detected only by ELISA IgM test. Recent infection with Borrelia burgdorferi was confirmed in 2.15\% (2/93) individuals, whereas IgG antibodies against Borrelia burgdorferi were detected in only one participant. The obtained results indicated that Usutu virus is active in the territory of South Bačka District contrary to Chikungunya virus as well as that Borrelia burgdorferi is an important pathogen in the investigated region.

Key words: Usutu virus, Chikungunya virus, Borrelia burgdorferi, ELISA IgG

\title{
SEROPREVALENCIJA MIKROORGANIZAMA KOJE PRENOSE KOMARCI I KRPELJI KOD HUMANE POPULACIJE U REGIONU JUŽNA BAČKA
}

\author{
Ivana Hrnjaković Cvjetković ${ }^{1,22}$, Tamas Petrovićc ${ }^{3}$, Dušan Petrićc, \\ Dejan Cvjetković2,5, Gordana Kovačević ${ }^{1}$, Jelena Radovanov ${ }^{1}$, \\ Aleksandra Jovanović Galović ${ }^{1}$, Aleksandra Patić, ${ }^{1,2}$, Nataša \\ Nikolić ${ }^{1,2}$, Sandra Stefan Mikić2,5, Vesna Miloševićc ${ }^{1,2}$ \\ ${ }^{1}$ Institut za javno zdravlje Vojvodine, Novi Sad, Republika Srbija \\ ${ }^{2}$ Medecinski fakutet, Univerzitet u Novom Sadu, Republika Srbija \\ ${ }^{3}$ Naučni institute za veterinarstvo "Novi Sad”, Novi Sad, Republika Srbija \\ ${ }^{4}$ Poljoprivredni fakultet, Univerzitet u Novom Sadu, , Republika Srbija \\ ${ }^{5}$ Klinički centar Vojvodine, Departman za infektivne \\ bolesti, Novi Sad, Republika Srbija
}

\section{Kratak sadržaj}

Chikungunya virus je Arbo virus iz porodice Togaviridae. U urbanim zonama antropofilne vrste komaraca Aedes aegypti i Aedes albopictus su vektori koji infekciju prenose na ljude. Chikungunya virus je privukao pa-

${ }^{2}$ Corresponding author: ivana.hrnjakovic@izjzv.org.rs, ivana.hrnjakovic-cvjetković@mf.uns.ac.rs 
žnju 2013. godine izazvavši veliku epidemiju na američkom kontinentu. U Evropi je registrovana autohtona transmisija Chikungunya virusa 2007. god. u Italiji i 2010. i 2014.god. u Francuskoj. Usutu virus je RNK virus iz porodice Flaviviridae. Održava se u transmisivnom ciklusu između divljih ptica i komaraca iz genusa Culex. Virus je dokazan u različitim vrstama evropskih ptica. Virus u čoveka izaziva meningoencefalitis i osip na koži. Prvi humani slučajevi u Evropi su registrovani u Italiji 2009. god. u imunodeficitarnih osoba.

Spiroheta Borrelia burgdorferi sensu lato se prenosi na ljude krpeljima i izaziva lajmsku bolest, multisistemsko oboljenje koje se ispoljava dermatološkim, neurološkim, kardiološkim manifestacijama i promenama na zglobovima. Pregledano je 93 ispitanika od kojih je anketiranjem dobijen podatak da su izloženi riziku inficiranja mikroorganizmima koje prenose vektori. Testiranje je izvršeno komercijalnim ELISA IgG na Chikungunya i Usutu virus te ELISA IgM i IgG testom na Borrelia burgdorferi, striktno prema uputstvima proizvođača (Euroimmun, Nemačka). Od 93 ispitanih osoba IgG antitela protiv usutu virusa nađena su u 7,5\% (7/93). Rezultat ELISA IgG testa na Chikungunya virus je bio negativan u većini testiranih uzoraka dok je u 7,5\% (7/93) uzorka rezultat bio graničan. U 9,7\% (9/93) ispitanika dokazana su antitela samo ELISA IgM testom na bakteriju Borrelia burgdorferi. U 2,15\% (2/93) ispitanika dokazana je nedavna infekcija bakterijom Borrelia burgdorferi. U jednog ispitanika dokazana su samo IgG antitela na Borrelia burgdorferi. Dobijeni rezultati ukazuju da je za razliku od Chikungunya virusa usutu virus aktivan na teritoriji Južnobačkog okruga kao i da je Borrelia burgdorferi značajan patogen na ispitivanom okrugu.

Ključne reči: Usutu virus, Chikungunya virus, Borrelia burgdorferi, ELISA IgG

\section{INTRODUCTION}

Chikungunya virus is an Arbo virus belonging to the family Togaviridae, genus Alphavirus. In African jungles, various nonhuman primates serve as the reservoir of Chikungunya virus after being infected by its vectors - various types of mosquitoes. Infected mosquitoes may transmit the virus to humans during the blood meal. In urban areas, antropophilic Aedes aegypti and Aedes albopictus mosquitoes are responsible for transmission of the disease (Weaver et al., 2012). Chikungunya virus causes a sudden onset of clinical symptoms, fever over $38,5^{\circ} \mathrm{C}$, polyarthralgia and skin rash. The prognosis is most commonly favorable, although hepatitis, Guillain-Barre syndrome, cardiologic and 
neurologic disorders like encephalitis, myelopathy and polyneuropathy may occur. The ability of Aedes aegypti and Aedes albopictus mosquitoes to colonize wide new geographic areas, facilitated by rapid development of international traffic and global climate changes, significantly contributes to Chikungunya virus expansion. Chikungunya virus has attracted the professional and scientific public attention in 2013 causing a massive outbreak on the American continent. Chikungunya virus infections have been recorded in Africa, Asia, Europe and on the islands in the Indian and Pacific Oceans before 2013. At the end of 2013, the first local transmission of Chikungunya virus on the American continent was recorded in the Carribean. Since then, almost 1.7 million chikungunya cases have been identified in 45 countries on the American continent (CDC, 2015). Local transmission of Chikungunya virus was reviewed in 198 cases in Puerto Rico and in 4 cases at the U.S. Virgin Islands (CDC, 2016).

Usutu virus is another arbovirus, belonging to the family Flaviviridae, serogroup of Japanese encephalitis. Usutu virus infection is endemically present in Africa, where the birds serve as the reservoir of infection, while the Culex mosquitoes play the role of the vector. African birds have become well adapted to Usutu virus during their evolution, so the infection goes mostly asymptomatically in these birds. In contrast, Usutu virus is highly virulent for European birds and the infection may result in necrotizing focal encephalitis, degenerative myocarditis and fatal encephalitis (Baconyi et al., 2007). The virus is presumed to be introduced into Europe by migratory birds that became infected during either living in or overflying of endemic areas in Africa. The first human cases have been recorded in immunocompomised persons in Italy (Pecorari et al., 2009). The virus causes meningoencephalitis and skin rash in humans (Cavrini et al, 2011).

Infection with spirochete Borrelia burgdorferi sensu lato is transmitted to humans by ticks and causes Lyme disease, a multisystemic disease with dermatological, neurological, cardiological or articular manifestations. Although even 13 different species of Borrelia belong to Borrelia burgdorferi sensu lato, one of those, Borrelia burgdorferi sensu stricto, is the most significant in the United States of America, whereas Borrelia afzelii and Borrelia garinii are the most important members of Borrelia species in Europe. Incidence of Lyme disease in the United States ranged from 7.0/100 000 (in 2012) to 9.8/100 000 (in 2009) during the period of 2004 - 2015, so as Lyme disease is the most common vector-borne disease in the United States. It is the most common tickborne disease in Europe as well. In endemic areas of the Euroasia, various species of vertebrates, small mammals and birds infested by larvae and nymphs of Ixodes ricinus ticks serve as reservoirs of Borrelia burgdorferi. 


\section{MATERIAL AND METHODS}

In 2015, 93 otherwise healthy persons referred to the Public Health Institute of Vojvodina for serological testing within regular pregnancy checkups or pre-operative preparation were examined. Persons were interviewed about risk factors for mosquito-borne or tick-borne infections such as outdoor recreational activities, professional stay in nature, exposure to the mosquitoes or use of the repellents. In total 53 (56.9\%) subjects were females, while 40 (43.1\%) were males. Sera were tested for the presence of Usutu and Chikungunya viruses by enzyme immunoassay (ELISA) for specific IgG antybodies and IgM and IgG for Borrelia burgdorferi (manufacturer Euroimmune, Lübeck, Gemany) on Analyzer I, Euroimmune.

\section{RESULTS}

IgG ELISA - positive results for Usutu virus were obtained in 7 (7.5\%) samples (four from males, three from females) with average age of 53.9 years. Among subjects seropositive on Usutu virus, $71.4 \%$ reported either outdoor or indoor exposure to the mosquitoes. 6/7 (85.7\%) subjects seopositive for Usutu virus live in rural areas, whereas $5 / 7$ of them (71.4\%) live close to the water. None of the tested subjects either has travelled abroad during the last year or has been vaccinated against yellow fever. In addition, none of tested subjects was positive on Chikungunya virus. Indeterminate results for Chikungunya virus were obtained in 7 subjects of average age 52.6 years.

In two subjects (2.15\%), acute Borrelia burgdorferi infection (both IgM ELISA and IgG ELISA positive) has been found; one of them was a 49 year old male and the other was a 22 year old female. In the case of one 21 year old female (1.07\%) there were only IgG antibodies against Borrelia burgdorferi found. Isolated IgM ELISA positive finding was identified in 9 (9.7\%) subjects, indicating probable infection, but only follow-up of the subjects with serological testing performed both in acute and convalescent sera was able to provide the final diagnosis.

\section{DISCUSSION}

Usutu virus has been found in the birds and/or mosquitoes in 12 European countries: Austria, Croatia, Czech Republic, Germany, Greece, Hungary, Italy, Spain, Serbia, United Kingdom, Switzerland and Belgium (Nikolay et al., 2015). Among neighboring countries, the presence of Usutu virus has 
been confirmed by detection of the virus in birds using reverse transcription polymerase chain reaction, immunohistochemistry and in situ hybridization (Bakonyi T., 2007). Usutu virus has been proven serologically in horses in Serbia during investigation on West-Nile virus seroprevalence (Lupulović et al., 2011). Symptomatic Usutu virus infections in humans have been described in two European countries: Italy and Croatia, which is our neighboring country (Vilibic - Čavlek et al., 2015, Nikolay et al., 2015). These findings encouraged the authors of this paper to investigate the Usutu virus seroprevalence in a minor sample of human population of Vojvodina. Antibodies against Usutu virus were confirmed in 7/93 (7.5\%) subjects by IgG ELISA. Taking into account that the West-Nile virus is active too in Serbia and cross-reactions with ELISA test among flaviviruses may occur, the results should be confirmed by more sensitive and more specific test, such as plaque reduction neutralization test (Petrić et al., 2012, Hrnjakovic et al., 2015).

As for European countries, autochthonous transmission of Chikungunya virus was registered in northeast Italy, where there were 205 cases during the period from July to September 2007. In addition, two autochthonous cases were registered in 2010 and 12 cases more in 2014 in France (Rezza G, 2007), (Gould, 2010). During the period 2008 - 2012, 51 Chikungunya cases were registered in European Union (ECDC, 2014). There have been no registered (even imported) Chikungunya cases in Serbia so far. Moreover, not a single case positive on Chikungunya virus has been identified in Serbia so far by serological examination.

According to reviewed data of the Institute of Public Health of Vojvodina, the incidence of Lyme disease was 8.3 in Serbia, respectively 5.7/100.000 residents in Vojvodina (Institute for Public Health of Serbia, 2014). Only 2/93 subjects had serological markers of acute infection (both positive IgM and IgG antibodies against Borrelia burgdorferi).

\section{CONCLUSION}

Obtained results showed that Usutu virus (unlike Chikungunya virus) is active in South Bačka District as well as that Borrelia burgdorferi is a significant pathogen in the same area.

\section{ACKNOWLEDGMENTS}

This work was financed by the Ministry of Education \& Science, Republic of Serbia - projects TR31084 and III43007 


\section{REFERENCES}

1. Bakonyi T., Erde'lyi K., Ursu K., Ferenczi E., Cso"rgo" T., Lussy H., et al.: Emergence of Usutu Virus in Hungary. Journal of Clinical Microbiology, 45, $12,3870-3874,2007$

2. Cavrini F., Dela Pepa ME., Gaibani P., Pierro AM., Rossini G., Landini MP et al.: A rapid and specific real-time RT-PCR assay to identify Usutu virus in human plasma, serum and cerebrospinal fluid. Journal of Clinical Virology, 50,3, 221-223, 2011

3. Centers for Disease Control and Prevention. Chikungunya virus, Geographic distruibution Available at: http://www.cdc.gov/chikungunya/geo/, October 20, 2015

4. Centres for Disease Control and Prevention. Chikungunya virus in the United States. Available at: http://www.cdc.gov/chikungunya/geo/unitedstates-2015.html, January 12, 2016

5. European Centre for Disease Prevention and Control. Annual epidemiological report 2014 - emerging and vector-borne diseases. Stockholm: ECDC; 2014. Available at: http://ecdc.europa.eu/en/publications/ Publications/emerging-vector-borne-diseases_annual-epidemiologicalreport-2014.pdf

6. Gould E.A., Gallian P., de Lamballerie X., R. N. Charre RN.: First cases of autochthonous dengue fever and chikungunya fever in France: from bad dream to reality! Clinical Microbiology and Infection, 16, 12,1702-1704, 2010

7. Hrnjakovic Cvjetkovic I., Petric D., Petrovic T., Kovacevic G., Radovanov J., Jovanovic Galovic A., et al.: Cross -reactions in serological diagnosis of flavivirus infections. Book of Abstracts, "One Health-New Challenges" First International Symposium of Veterinary Medicine (ISSVM 2015), May 21-23, 2015, editor in chief Tamas Petrovic, Vrdnik organized by Scientific Veterinary Institute Novi Sad and Institute of Veterinary Medicine of Serbia, p 229-233

8. Institute of Public Health of Srbia. Health Statistical Yearbook of Republic of Serbia 2014. Available at: http://www.batut.org.rs/download/publikacije/pub2014.pdf, 2015

9. Lupulović D., Martín-Acebes M.A., Lazic S., Alonso-Padilla J., Blazquez A.B., Escribano-Romero E., et al.: First Serological Evidence of West Nile Virus Activity in Horses in Serbia. Vector-Borne and Zoonotic Diseases, 11, 1303-1305, 2011

10. Nikolay B.: A review of West Nile and Usutu virus co-circulation in Europe: how much do transmission cycles overlap? Transactions Royal Soc 
Tropical Med \& Hyg, 109, 609-618, 2015

11. Pecorari M., Longo G., Gennari W., Grottola A., Sabbatini A., Tagliazucchi S., et al.: First human case of Usutu virus neuroinvasive infection, Italy, August-September 2009. Euro Surveillance, 14,.50,pii:19446, 2009 Available at: http://www.eurosurveillance.org/ViewArticle.aspx? ArticleId=19446

12. Petric D., Hrnjakovic Cvjetkovic I., Radovanov J., Cvjetkovic D., Jerant Patic V., Milosevic V., et al.: West Nile virus surveillance in humans and mosquitoes and detection of cell fusing agent virus in Vojvodina province (Serbia). HealthMed, 6,2, 462-468, 2012

13. Rezza G., Nicoletti L., Angelini R ., Romi R., Finarelli AC., Panning M et al.: Infection with chikungunya virus in Italy: an outbreak in a temperate region. Lancet, 370, 9602, 1840-1846, 2007

14. Vilibić-Čavlek T., Barbić L., Stevanović V., Mlinarić Galinović G.: Usutu virus: a novel flavivirus in Croatia. Lijecnički Vjesnik, 137,1-2,46-51, 2015 [Article in Croatian]

15. Weaver S.C., Osorio JE., Livengood JA., Chen R., Stinchcomb DT.: Chikungunya virus and prospects for a vaccine. Expert Rev Vaccines, 11,9, 1087-1101, 2012

Primljeno: 20.07.2016.

Odobreno: 15.09.2016. 